\title{
Pergeseran Etika Profesi Jurnalis Pada Wartawan yang Menyambi Sebagai Endorser di Instagram
}

\author{
Maya Rachmawaty, Nicky Stephani, dan Reni Dyanasari \\ Fakultas Humaniora dan Bisnis, Universitas Pembangunan Jaya \\ mayaa.rachmaa@gmail.com
}

\begin{abstract}
Nowadays, endorsement or paid promotion activities through Instagram are not only done by celebrities but also by people from other professions with many followers such as television journalists. The journalists who play an important role as the fourth pillar of a democratic nation are immersed in digital euphoria by participating in endorsement activities. This certainly leaves ethical problems. Based on the Indonesian Journalist Code of Ethics, a journalist must be independent and prohibited to misuse their profession to benefit certain parties. Therefore, this research was conducted to study this phenomenon, especially in understanding the attitudes and perceptions of journalists towards their endorsement or paid promotion activities. This research was conducted using a descriptive-qualitative approach with semi-structured in-depth interview. Five informants, consisting of journalists from several television stations (SCTV, TV One and Kompas TV), were interviewed. The results show that the journalist's motives in doing the endorsement are helping small businesses and obtaining financial benefits. Four informants believe that the endorsement activities do not violate the Journalistic Code of Ethics as long as they only talk about the facts and do not spread lies, while, the other one thinks it certainly do. Their perceptions were influenced by their membership of professional association and ownership of professional certification. The informants who agreed that the endorsement activities are not in accordance with the code of ethics, has a membership of Indonesian Television Journalists Association and also has a professional certification as senior journalist, while the other informants lack such credibility.
\end{abstract}

Keywords: journalistic code of ethics; endorsement; paid promotion; television journalist; professionalism

\begin{abstract}
Abstrak
Praktik endorsement atau promosi berbayar melalui Instagram kini bukan hanya dilakukan oleh kalangan selebriti. Jurnalis televisi yang mengemban peran penting sebagai pilar keempat negeri ini juga larut dalam arus euforia digital dengan turut melakukan kegiatan endorsement. Hal ini tentu meninggalkan permasalahan etika, karena sesuai dengan Kode Etik Jurnalistik Wartawan Indonesia, jurnalis haruslah bersifat independen dan tidak menyalahgunakan profesinya untuk menguntungkan suatu pihak. Penelitian ini dilakukan untuk mempelajari fenomena tersebut, terutama melihat sikap dan tanggapan para jurnalis terhadap kegiatan promosi berbayar di Instagram yang dilakukannya. Penelitian ini dilakukan dengan menggunakan pendekatan deskriptif-kualitatif dengan teknik pengambilan data melalui wawancara mendalam. Terdapat lima informan yang berhasil diwawancara, berasal dari stasiun televisi SCTV, TV One dan Kompas TV. Hasil penelitian menunjukkan para jurnalis kerap melakukan endorsement di Instagram dengan berbagai motif seperti membantu usaha kecil dan menengah, serta mendapatkan keuntungan finansial. Empat informan meyakini praktik endorsement tidak menyalahi kode etik selama masih mengedepankan fakta dan tidak menyebarkan kebohongan, sementara satu informan percaya hal tersebut melanggar kode etik. Persepsi informan dipengaruhi oleh keanggotaan organisasi profesi dan kepemilikan sertifikasi profesional. Jurnalis yang menganggap kegiatan endorsement tidak sesuai dengan kode etik, tercatat sebagai anggota Ikatan Jurnalis Televisi Indonesia dan memiliki setifikasi jurnalis utama, sementara informan lainnya tidak.
\end{abstract}

Kata kunci: kode etik jurnalistik; endorsement; promosi berbayar; jurnalis televisi; profesionalitas

Korespondensi: Maya Rachmawaty, S.Pt., M.Sc., Fakultas Humaniora dan Bisnis Universitas Pembangunan Jaya, Jalan Cendrawasih Raya Blok B7/P, Sawah Baru, Kec. Ciputat, Kota Tangerang Selatan, Banten 15413, Email: mayaa.rachmaa@gmail.com

Menyerahkan: Maret 2021, Diterima: Oktober 2021, Terbit: Januari 2022

ISSN: 2549-0559 (cetak), ISSN: 2549-1946 (online), Website: http://jurnal.unpad.ac.id/kajian-jurnalisme 
116 | Kajian Jurnalisme

Volume 05 Nomor 02 Tahun 2022

DOI: $10.24198 / j \mathrm{kj} . v 5 \mathrm{i} 2.32822$

\section{PENDAHULUAN}

Fenomena jurnalis televisi yang menjadi endorser untuk berbagai produk di media sosial seperti Instagram semakin marak terjadi dalam beberapa tahun terakhir (Elliot \& Spence, 2017). Secara sadar, jurnalis yang seharusnya menjadi sosok yang independen, menerima bayaran dengan memberikan komentar positif terhadap sebuah produk dalam unggahan foto atau video di akun Instagram pribadinya. Bukan hanya itu, mereka pun sering kali tidak memberikan keterangan ataupun tanda bahwa unggahan tersebut merupakan endorsement atau promosi berbayar (Elliot \& Spence, 2017). Menurut Mubarikah (2021) kegiatan endorsement tanpa keterangan promosi di media sosial melanggar atau tidak sesuai dengan Undang-Undang perlindungan konsumen.

Fenomena ini meninggalkan masalah etika profesi. Berdasarkan pasal 7 Undang-Undang RI Nomor 40 Tahun 1999 tentang Pers, setiap jurnalis wajib menaati Kode Etik Jurnalistik. Kode Etik Jurnalistik telah mengalami beberapa perubahan, di mana yang terbaru ditetapkan oleh Dewan Pers pada 14 Maret tahun 2006 lalu. Dari total 11 pasal yang ada dalam Kode Etik Jurnalistik, kegiatan endorsement atau rekomendasi produk yang berbayar tidak sesuai dengan pasal 1 dan 6. Pasal satu menyebutkan "Wartawan Indonesia bersikap independen, menghasilkan berita yang akurat, berimbang, dan tidak beritikad buruk" (Dewan Pers Republik Indonesia, 2006). Dalam pasal 1 ditegaskan wartawan haruslah independen, namun dalam melakukan kegiatan endorsement, wartawan disponsori oleh sebuah badan usaha. Selanjutnya, pasal 6 menyebutkan "Wartawan Indonesia tidak menyalahgunakan profesi dan tidak menerima suap" sementara dalam kegiatan endorsement wartawan menyalahgunakan profesi atau ketenarannya untuk mempromosikan produk dari sebuah badan usaha.

Selain terkait problematika etika, masalah ini penting untuk menjadi objek penelitian mengingat jumlah pengguna Instagram yang setiap tahunnya kian bertambah. Berdasarkan data dari NapoleonCat, analis pemasaran media sosial dari Polandia, jumlah active user Instagram di Indonesia hingga 2020 lalu adalah sebesar 69.270.000 pengguna. Kemudian, model promosi endorsement-influencer pun telah terbukti efektif untuk meningkatkan minat beli konsumen dan angka penjualan produk (Elliot \& Spence, 2017; Patimah \& Gorda, 2017; Wati, 2019). Untuk itu, perlu sebuah tindakan agar pergeseran nilai etika profesi jurnalis tidak memberikan kontribusi lebih lanjut pada kegiatan promosi ini, karena praktik yang mencampuradukkan antara kewartawanan dan periklanan akan berakibat pada menurunnya tingkat kepercayaan masyarakat terhadap jurnalis untuk mendapatkan informasi yang independen (Pitakasari, 2013).

Permasalahan pelanggaran etika dalam kegiatan endorsement di akun pribadi jurnalis sebenarnya bukanlah hal yang baru. Sebelum dunia media sosial berkembang seperti saat ini, kegiatan soft-promotion atau product endorsement sering kali dimasukkan dalam pengerjaan editorial berita, sehingga penyampaian fakta menjadi bias (Muela-Molina, Martin-Santana, \& Reinaress-Lara, 2020). Perbedaanya terletak pada media yang digunakan yakni akun pribadi media sosial masing-masing jurnalis. Meskipun akun pribadi hal ini tetap tidak sesuai etika, karena dalam akun pribadinya, jurnalis tetap mencitrakan bahwa dirinya adalah seorang jurnalis. Dalam permasalahan pelanggaran etika yang berhubungan dengan uang atau hadiah, Pramesti (2014) menyatakan salah satu alasan yang mendorong para jurnalis untuk menerima hadiah, uang maupun keuntungan lainnya dari pihak tertentu dalam kegiatan peliputan adalah karena gaji jurnalis yang kecil, di mana perusahaan media tempatnya bekerja belum dapat memberikan upah yang layak bagi para jurnalisnya.

Oleh karena itu, penelitian ini bertujuan untuk mendapatkan perspektif dari sisi pelaku, dalam hal ini para jurnalis yang melakukan kegiatan endorsement di akun Instagramnya, guna memperluas pengetahuan terkait fenomena journalist-endorser. Di mana pada akhirnya akan 
menambah kajian teoritis terkait etika profesi jurnalis di era digital. Hasil penelitian dapat dijadikan bahan acuan untuk peninjauan ulang kembali relevansi etika profesi jurnalis di era digital, agar dapat mewujudkan dan/atau mengembalikan profesi jurnalis yang profesional dan berintegritas.

\section{METODE}

Kerangka berpikir penelitian dimulai dari konsep perkembangan media digital, khususnya media sosial Instagram yang membentuk suatu kegiatan promosi baru yakni endorsement, yang dilakukan oleh public figure, bukan hanya selebriti namun juga jurnalis khususnya jurnalis televisi yang memiliki popularitas atau dikenal publik karena kerap muncul di media massa. Kemunculan fenomena endorsement oleh jurnalis ini menimbulkan permasalahan etika pasalnya jurnalis seharusnya memegang prinsip independen, tidak menyalahgunakan profesi untuk kepentingan pihak tertentu.

Maka dari itu, penelitian ini bertujuan untuk mempelajari lebih dekat fenomena munculnya jurnalis televisi yang juga aktif melakukan kegiatan endorsement di Instagram. Dengan melihat perspektif pelaku atau pemeran utama dalam fenomena ini, yakni jurnalis itu sendiri. Adapun rumusan masalah penelitian ini adalah sebagai berikut: "Bagaimana sikap atau tanggapan jurnalis terhadap fenomena journalist-endorser?". Guna menjawab rumusan masalah ini, penelitian menggunakan pendekatan deskriptif-kualitatif. Berdasarkan Herdiansyah (2010), penelitian kualitatif bertujuan untuk memahami sebuah kejadian yang tengah dirasakan oleh subjek penelitian, termasuk di dalamnya perilaku, persepsi, motivasi, dan tindakan.

Selanjutnya, sistem pengambilan data dilakukan dengan wawancara mendalam (indepth interview) di mana pertanyaan disusun dengan format semi-structured interview. Pertanyaan sudah dalam tatanan susunan tertentu agar mudah untuk dibandingkan jawabannya antar informan, namun setting wawancara masih membuka ruang untuk pertanyaan lanjutan guna mengklarifikasi jawaban informan lebih mendalam, jika dibutuhkan (Kothari, 2004). Teknik pemilihan informan menggunakan sistem purposive sampling. Informan dipilih sesuai dengan sejumlah kriteria, agar hasil wawancara relevan dengan masalah penelitian (Bungin, 2011: 107). Dalam penelitian ini informan yang diwawancara telah memenuhi sejumlah kriteria di antaranya; informan merupakan jurnalis televisi yang memiliki akun Instagram dan pernah melakukan endorsement produk. Kriteria informan telah disesuaikan dengan objek penelitian. Terdapat 5 (lima) informan yang diwawancara, berasal dari beberapa media televisi yakni SCTV, TV One dan Kompas TV. Pengambilan data dengan wawancara dilakukan pada tanggal 29 Juli - 9 Agustus 2020 di Jakarta. Untuk memastikan kredibilitas data, dilakukan uji conformability. Pengolahan data dilakukan dengan Analisa open, axial and selective coding.

\section{HASIL DAN PEMBAHASAN}

\section{Informan Penelitian}

Penelitian telah dilakukan dengan mewawancarai lima informan yang merupakan jurnalis dari beberapa stasiun televisi yakni SCTV, TV One dan Kompas TV. Nama informan dirahasiakan mengingat isu yang dibahas cukup sensitif dan berpotensi untuk merugikan informan bila diungkapkan. Adapun deskripsi data informan tersaji dalam Tabel 1. 
118 | Kajian Jurnalisme

Volume 05 Nomor 02 Tahun 2022

DOI: $10.24198 / j \mathrm{kj} . v 5 \mathrm{i} 2.32822$

Tabel 1. Data Informan

\begin{tabular}{|c|c|c|c|c|c|}
\hline No & Informan & $\begin{array}{c}\text { Pengalaman } \\
\text { Bekerja Sebagai } \\
\text { Jurnalis }\end{array}$ & $\begin{array}{c}\text { Jumlah } \\
\text { Pengikut } \\
\text { (followers) di } \\
\text { Instagram }\end{array}$ & $\begin{array}{c}\text { Banyaknya } \\
\text { Kegiatan } \\
\text { Endorsement } \\
\text { (per bulan) }\end{array}$ & $\begin{array}{c}\text { Tarif Endorsement } \\
\text { (rupiah) }\end{array}$ \\
\hline 1 & Informan 1 & 12 tahun & 44.700 & $4-5$ & $200.000-500.000$ \\
\hline 2 & Informan 2 & 12 tahun & 24.000 & 1 & - \\
\hline 3 & Informan 3 & 6 tahun & 44.000 & $2-3$ & $1.000 .000-3.000 .000$ \\
\hline 4 & Informan 4 & 11 tahun & 50.000 & $4-8$ & $0-500.000$ \\
\hline 5 & Informan 5 & 8 tahun & 43.300 & $8-12$ & 2.000 .000 \\
\hline
\end{tabular}

Sumber: Hasil Penelitian, 2020

Dalam Tabel 1 dapat dilihat bahwa kelima informan yang diwawancarai memiliki pengalaman bekerja sekitar 6 hingga 12 tahun, dengan jabatan sebagai reporter hingga produser berita. Jumlah follower atau pengikut dari akun Instagram masing-masing informan bervariasi mulai dari 24.000 hingga 50.000 pengikut. Informan 1, 3, 4 dan 5 tidak bergabung dalam organisasi profesi jurnalis, dan belum memiliki sertifikasi kompetensi wartawan, sementara informan 2, tergabung dalam Ikatan Jurnalis Televisi Indonesia (IJTI) dan memiliki sertifikasi jurnalis utama.

Selanjutnya, informan 1, 2 dan 4 tidak menentukan tarif khusus dalam kegiatan endorsement-nya terutama untuk Usaha Mikro, Kecil dan Menengah (UMKM). Namun untuk perusahaan yang sudah mapan atau brand besar, informan 1, 2 dan 4 biasanya mendapatkan kompensasi sekitar Rp200.000 hingga Rp500.000. Ketiga informan juga mengaku tidak terlalu sering melakukan kegiatan endorsement, hanya sekitar 1-8 kali setiap bulannya, itu pun kebanyakan dari teman atau saudara yang baru merintis bisnis dengan produk makanan dan minuman. Bagi Informan 1, 2 dan 4, alasan utama mereka melakukan endorsement di akun instagramnya adalah untuk membantu usaha orang-orang yang ada di sekitarnya terutama di masa pandemi ini. Sementara itu, informan 3 dan 5 menetapkan tarif khusus untuk kegiatan endorsement-nya dengan kisaran harga Rp1.000.000 hingga Rp3.000.000. Mereka pun mengaku cukup sering melakukan kerja sama endorsement yakni sekitar 2 hingga 12 kali dalam satu bulan. Tidak selalu berupa uang tunai, terkadang mereka menerapkan sistem barter product, dengan nilai produk sama dengan tarif yang ditetapkan.

\section{Motivasi Jurnalis dalam Menggunakan Instagram}

Rata-rata informan menyatakan motivasi awal untuk mendaftar dan ikut aktif menggunakan Instagram adalah hanya iseng-iseng mengikuti tren social media. Namun seiring berkembangnya dunia media sosial, kini para informan menggunakan Instagram untuk beberapa alasan di antaranya untuk membentuk citra pribadi (personal branding), memperluas pergaulan dan mendapatkan pekerjaan tambahan. Seperti yang disampaikan oleh Informan 5:

"Ya kalau sekarang sih iya, ternyata sekarang Instagram ya enggak cuma buat berteman aja. Bisa juga buat nambah link, buat kerjaan, terus juga personal branding di sana. Dan ya, kaya apa ya... kalau side job, iya. Buat hal-hal kayak gitu lah, lebih luas sekarang." (Informan 5, Wawancara. 9 Agustus 2020)

Beberapa juga menyatakan Instagram dapat digunakan untuk mencari informasi dan hiburan. Seperti yang disampaikan oleh Informan 4:

"Agar terkoneksi dengan orang-orang dan tetep update dengan seluruh informasi di social media, gitu. Kadang kan kalau misalnya kita mau nyari berita misalnya kita buka artikel tapi kan fenomena social media ini biasanya berbeda lagi, nah makannya perlu 
gabung di Instagram.” (Informan 4, Wawancara. 8 Agustus 2020)

Hal ini sejalan dengan beberapa penelitian sebelumnya terkait motivasi dalam menggunakan media sosial khususnya Instagram. Berdasarkan hasil penelitian Syahreza dan Tanjung (2018) serta Alfindra dan Yahya (2017), motivasi seseorang dalam menggunakan Instagram adalah untuk mendapatkan hiburan, informasi, sebagai bentuk aktualisasi diri dan motif ekonomi seperti berbisnis.

Dalam menggunakan media sosial Instagram, para jurnalis mengisi akunnya dengan unggahan tentang pekerjaan dan kehidupan sehari-hari. Seluruh informan menunjukkan profesinya sebagai jurnalis dan media tempatnya bekerja pada akun Instagramnya, seperti yang disampaikan oleh Informan 2 dan Informan 5:

"Menunjukkan banget sih (profesi sebagai jurnalis), jadi kalau misalnya kerjaan.. kebanyakan kalau kerjaan pasti akan sudah ketahuan lah kerjanya di mana, mungkin pas siaran (pernah lihat), pas lagi liputan, jadi pasti keliatan banget." (Informan 5, Wawancara. 9 Agustus 2020)

Semua informan menuliskan di biodata instagramnya bahwa dirinya adalah seorang jurnalis, bahkan mereka juga menuliskan nama media dan program tempatnya bekerja. Selain itu, untuk kepentingan personal branding dan promosi karya, mereka pun mengunggah beberapa karya jurnalistiknya di akun Instagramnya. Untuk kegiatan promosi, biasanya mereka membuat cuplikan program yang sedang dikerjakannya dan mengunggahnya di akun Instagram masing-masing untuk membantu promosi agar semakin banyak masyarakat yang menontonnya di televisi. Serta, setelah liputan atau program tayang, informan pun mengunggahnya ke dalam sosial media mereka sebagai bahan untuk personal branding, yakni dengan menunjukkan beberapa karya terbaiknya. Jadi, jelas dari keterangan tersebut bahwa para informan masih membawa profesinya ke dalam akun media sosial mereka, meskipun itu adalah akun milik pribadi.

Selanjutnya, karena memperlihatkan profesinya sebagai jurnalis di media sosialnya, para informan pun mengaku mereka harus berhati-hati dalam bersosial media, agar tidak mengunggah sesuatu yang tidak pantas seperti konten yang mengandung SARA, pornografi, maupun keberpihakan terutama dalam berpolitik, sebagaimana yang disampaikan Informan 5:

"Nah tapi memang gak bisa dilepasin juga walaupun akun itu kan akun pribadi. Jadi apa yang aku posting juga gak boleh seenak-enaknya. Misalnya nih.. berpakaian, aku ga bisa tuh pakaian yang seenak-enaknya. Terus kontennya juga ga bisa terpisah sama aku yang profesiku jurnalis dan kantorku juga. Jadi ya.. tetap harus berhati-hati dalam bermedia sosial. Batasannya sih ya tidak mengandung SARA, tidak mengandung hal-hal yang tidak elok untuk ditampilkan. Apalagi misalnya, ini contoh aja.. Misalnya waktu pilpres kemarin, gak boleh hal-hal yang menjurus, misalnya mendukung ke pasangan calon tertentu gitu.. Karena kan gimana pun juga gak bisa terpisah profesi kita, meskipun misalnya kita punya pilihan pribadi." (Informan 5, Wawancara. 9 Agustus 2020)

Dapat dilihat dari pernyataan Informan 5, ia mengaku berhati-hati dalam menggunakan Instagram karena profesinya sebagai jurnalis. Terdapat seleksi konten yang dilakukan namun mempromosikan produk dengan skema endorsement bukanlah salah satu hal yang dihindarinya.

\section{Kegiatan Product-Endorsement para Jurnalis}

Endorsement merupakan kegiatan promosi secara tidak langsung (soft selling) dengan meminta selebriti, tokoh atau public figure untuk memberikan testimoni positif akan sebuah produk (De Veirman, Cauberghe, \& Hudders, 2017). Teknik promosi ini sering kali digunakan untuk upaya promosi di media sosial. Kegiatan endorsement terbukti efektif untuk meningkatkan minat beli konsumen, serta memudahkan para penjual atau pengusaha untuk menjangkau target konsumennya (Andriawan, 2016; Breves et al., 2019; Elliot \& Spence, 2017; Patimah \& Gorda, 
120 | Kajian Jurnalisme

Volume 05 Nomor 02 Tahun 2022

DOI: $10.24198 / \mathrm{jkj} . v 5 \mathrm{i} 2.32822$

2017). Bukan hanya menggunakan selebriti, kini praktik endorsement di Instagram pun sering kali dilakukan oleh masyarakat umum yang memiliki banyak pengikut atau followers, tidak terkecuali jurnalis televisi.

Secara garis besar, kegiatan endorsement para jurnalis dapat dibagi menjadi dua skema yakni barter-product dan berbayar. Informan 1, 2 dan 4 lebih sering melakukan endorsement barter-product yakni pengusaha hanya mengirimkan produk tanpa dipungut biaya sama sekali di mana kliennya kebanyakan merupakan pengusaha kecil dan menengah. Sementara Informan 3 dan 5, selain menerima barter-product, mereka juga melakukan endorsement dengan skema berbayar. Informan 3 menetapkan tarif sekitar Rp1.000.000 hingga Rp3.000.000 tergantung konten unggahan yang diinginkan klien. Untuk sekadar foto atau instastory biaya yang dikenakan sekitar Rp1.000.000, namun untuk endorsement dengan pembuatan video dikenakan biaya Rp 3.000.000. Sedangkan Informan 5 menetapkan tarif sekitar Rp2.000.000 per paket endorsement termasuk instastory, foto dan video. Biaya yang ditetapkan untuk endorsement produk dari perusahaan brand besar lebih tinggi dibandingkan UMKM, karena perusahaan brand besar secara finansial telah lebih stabil. Tetapan harga ini dibuat oleh informan, karena proses produksi konten endorsement cukup menyita waktu dan energi serta mempertimbangkan keuntungan promosi yang didapatkan kliennya.

Selanjutnya, alasan utama para informan mengambil tawaran untuk product endorsement adalah ingin membantu rekan atau kenalannya yang memiliki bisnis kecil dan menengah, seperti yang disampaikan Informan 2 "Membantu, bener-bener pure untuk membantu orang-orang ini mempromosikan, jadi sama sekali ga ada niatan yang lain-lain". Bahkan di masa pandemi ini seluruh informan mengaku memberlakukan endorsement gratis bagi UMKM, seperti yang disampaikan Informan 4:

"Terutama sekarang-sekarang ini setelah pandemi orang kan banyak yang ya susah ya sekarang secara ekonomi nih di mana-mana akhirnya banyak yang memulai bisnisbisnis baru. Jadi sebagai sarana saling membantu ajalah gitu maksudnya, apalagi si yang banyak kita bisa lakukan mungkin kita gak bisa kan nyumbang dana besar gitu untuk membantu mereka kaya yang ekonominya terganggu, tapi kan hal kecil seperti itu kan bisa kita lakukan ada yang mulai bisnis terus mungkin mereka ngirim makanan terus kita review ini rasanya gimana gitu." (Informan 4, Wawancara. 8 Agustus 2020)

Selain itu juga ada motivasi lain yakni keuntungan materi dan bahan untuk dijadikan konten, seperti yang disampaikan Informan 3 "Karena untuk personal branding juga dan di samping itu juga ada keuntungan buat kita, ya kita ambil aja dan sesuai dengan profile aku, jadi ya aku post juga aja". Bagi Informan 3 dan 5, penghasilan tambahan dari endorsement bisa mencapai 20\%-30\% dari penghasilan tetap mereka setiap bulannya. Namun motif finansial ini tidak absolut, karena informan meskipun memiliki rate card (tetapan harga) untuk endorsement, sering kali juga hanya melakukan barter, yang terpenting memberikan manfaat atau berguna bagi kedua belah pihak seperti yang disampaikan oleh Informan 5:

"Sebenernya ya, saling bantu aja sih ya.. Kan gak semua endorsement itu yang aku harus patok harga sekian misalnya. Ada misalnya selama pandemi ini untuk UMKM gitu lokal, aku juga mau barter product.. untuk saling mempromosikan, gitu loh. Ada juga yang aku pakai product-nya dan aku cocok, yaudah kita kerja sama. Memang ada rate card tertentu sih ya, tapi yah seenggaknya itu ya balik lagi yang tadi.. yang sama-sama saling menguntungkan aja kan. Tapi harus product yang aku juga pakai." (Informan 5, Wawancara. 9 Agustus 2020)

Motivasi kegiatan endorsement para jurnalis yakni untuk membantu usaha mikro, kecil dan menengah, sebagai bahan konten media sosial, serta keuntungan finansial, sedikit berbeda dengan masyarakat umum. Hasil penelitian sebelumnya yang dilakukan oleh Febriana (2017) menunjukkan bahwa bentuk endorsement di Instagram yang dilakukan oleh masyarakat umum 
terutama mahasiswa dilandasi dengan keinginan mendapatkan pengakuan atau eksistensi. Semakin banyak konten endorsement yang diunggah ke Instagram berarti semakin populer individu tersebut (Febriana, 2017).

Selanjutnya, informan mengaku cukup pemilih dalam menentukan produk apa saja yang dapat mereka rekomendasikan. Akun media sosial perusahaan atau penjual merupakan saringan pertama yang dipertimbangkan informan dalam menerima permintaan endorsement, seperti yang disampaikan oleh Informan 1:

"Satu, harus jelas dulu nih produk apaan, aman ga kalau dikonsumsi, sama orangnya juga. Oke mungkin gue gak mengkonsumsi itu gak apa-apa, Cuma buat foto doang terus gue dapet duit buat sekali belanja ke supermarket gitu kan, tapi kan gue juga harus tau ini produk aman atau engga, ini akunnya (penjualnya) kayanya meyakinkan atau engga, pertama kali yang gue lihat adalah accountnya dulu." (Informan 1, Wawancara. 29 Juli 2020)

Selain pihak pengusaha, produk adalah bahan pertimbangan berikutnya. Sebagai jurnalis penting bagi informan untuk menjaga kredibilitasnya, jadi tidak sembarang produk mereka endorsement atau rekomendasikan seperti yang disampaikan Informan 4:

"Yang dilihat siapa dulu yang nawarin misalnya kalau itu usaha-usaha rumahan ya udah boleh aja mau kirim boleh silakan gitu, tapi kalau misalnya itu brand besar nah dilihat lagi lebih lanjut produknya ini memang apa, terus udah gitu pasarnya dia itu siapa gitu, kalau misalnya pun merasa misalnya ohhh aku ga cocok untuk mereview, ini bukan bidang aku misalnya gitu atau gak ini bukan sesuatu yang aku nikmati." (Informan 4, Wawancara. 8 Agustus 2020)

Jenis produk yang biasanya para informan terima adalah makanan dan minuman, baju, masker, perawaatan kecantikan professional seperti klinik kecantikan serta beragam produk lainnya yang sedang mereka butuhkan. Informan menghindari produk-produk yang tidak terjamin keamanannya seperti pemutih kulit dan pelangsing instan atau produk sejenisnya. Selain meyangkut permasalahan etika profesi, kegiatan promosi kosmetik ilegal bertentangan dengan UU No. 8 Tahun 1999 tentang Perlindungan Konsumen sang aktor promosi dapat dijatuhi hukuman pidana 6 tahun penjara dan denda maksimal Rp1.000.000.000,- (Mego, Budiartha, \& Ujianti, 2021).

\section{Kode Etik Jurnalistik dalam Kegiatan Endorsement}

Seperti yang telah dibahas sebelumnya ketika jurnalis melakukan promosi produk yang dibayar atau mendapatkan keuntungan (berupa produk gratis) dari sebuah badan usaha, maka setidaknya telah menyalahi pasal 1 dan pasal 6 Kode Etik Jurnalistik yakni wartawan harus independen dan tidak menyalahgunakan profesinya. Saat ditanya tentang penilaiannya apakah kegiatan endorsement di akun pribadi Intagram masing-masing menyalahi Kode Etik Jurnalistik atau tidak, jawaban yang diberikan pun beragam dapat dilihat selengkapnya dalam Tabel 2. 
122 | Kajian Jurnalisme

Volume 05 Nomor 02 Tahun 2022

DOI: $10.24198 / j \mathrm{kj} . v 5 \mathrm{i} 2.32822$

Tabel 2. Penilaian Jurnalis Terhadap Kegiatan Endorsement di Instagram

\begin{tabular}{|c|c|c|c|c|}
\hline No & Informan & $\begin{array}{c}\text { Keanggotaan } \\
\text { Organisasi Profesi } \\
\text { Jurnalis }\end{array}$ & $\begin{array}{c}\text { Sertifikasi Profesi } \\
\text { Jurnalis }\end{array}$ & $\begin{array}{c}\text { Penilaian Kegiatan } \\
\text { Endorsement berdasarkan } \\
\text { Pemahamannya tentang } \\
\text { Kode Etik Jurnalistik }\end{array}$ \\
\hline 1 & Informan 1 & - & - & Tidak Melanggar \\
\hline 2 & Informan 2 & IJTI & Jurnalis Utama & Melanggar \\
\hline 3 & Informan 3 & - & - & Tidak Melanggar \\
\hline 4 & Informan 4 & - & - & Tidak Melanggar \\
\hline 5 & Informan 5 & - & - & Tidak Melanggar \\
\hline
\end{tabular}

Sumber: Hasil Penelitian, 2020

Informan 3 secara spontan memberikan jawaban bahwa kegiatan endorsement tidak sesuai dengan Kode Etik Jurnalistik dengan mengatakan "Gak.. hahaha.. gimana dong ya namanya orang ngiklan". Namun lebih lanjut dirinya menjelaskan jika informasi yang diberikan dalam kegiatan endorsement sesuai fakta dan tidak membohongi publik maka sah saja untuk dilakukan. Pendapat ini pun sejalan dengan cara pandang Informan 1, 4 dan 5 terhadap kegiatan endorsement.

Informan 1, 4 dan 5 menyatakan selama niatnya baik untuk membantu orang dan tidak hard selling serta mengedepankan fakta, maka kegiatan endorsement sejalan dengan Kode Etik Jurnalistik, sebagaimana disampaikan Informan 5:

"Endorsement itu melanggar gak? Kalau menurut aku nggak, tapi kalau tujuannya buat apa dulu. Karena kalau kita misalnya kita hanya menceritakan kehidupan kita sehari-hari lewat endorsement atau product yang kita gunakan sehari-hari itu kan kayak kita bercerita di media sosial. Tapi kalau misalkan kita sudah campaign, menggiring untuk hal tertentu di luar tugas kita sebagai jurnalis atau mempengaruhi orang dengan apa pandangan kita terkait dengan profesi kita sebagai jurnalis nah itu bisa dibilang melanggar. Makanya tergantung dulu endorsement-nya apa tujuannya. Kalau aku kan tujuan endorsement-nya misalkan kayak ngebantu orang UMKM, itu kan nggak." (Informan 5, Wawancara. 9 Agustus 2020)

Informan 4 pun menambahkan yang terpenting selain mengedepankan fakta, produk yang dipromosikan tidak merusak kredibilitasnya sebagai jurnalis. Sehingga proses seleksi produk dalam penerimaan endorsement menjadi tahap yang penting. "Jangan sampai menerima produk seperti pembesar payudara atau pemutih kulit instan yang tidak masuk akal atau tidak dapat dipercaya. Seperti yang sampaikan Informan 4 "Sebenernya pokoknya intinya jangan sampai itu merusak kredibilitas kita lah sebagai jurnalis. Kaya misalnya gini tahu-tahu lu ngiklannya pembesar payudara gitu ya kan atau engga hmm misalnya minuman keras gitu".

Sementara, Informan 2 memiliki pendapat yang berbeda. Dirinya merasa kegiatan endorsement tidak sesuai dengan Kode Etik Jurnalistik, sebagaimana yang dijelaskannya:

"Iya sih sebenernya harusnya ga boleh, karena itu tadi... ini kan profesi yang bukan profesi yang main-main gitu, jadi makanya kenapa ada kode etik nya biar tidak bias. Karena untuk menghindari bias information yang kita sampaikan. Karena kita kan bekerja nya untuk memberikan informasi kepada publik tapi kalau kita ada kepentingan dengan si narasumber, itu akan bahaya. Ya itu emang agak-agak...memang benar, sebenernya sih emang ga boleh yaa." (Informan 2, Wawancara. 8 Agustus 2020)

Maka dari itu dirinya (Informan 2) membatasi hanya menerima permintaan dari temannya yang kebetulan memiliki usaha. Jadi jika ia mengunggah tentang suatu produk hanya sebagai ungkapan terima kasih telah dikirimkan produk bukan dimaksudkan untuk promosi. Lebih lanjut Informan 2 menyatakan, jika klien endorsement merupakan brand besar maka bukan saja 
melanggar kode etik jurnalistik namun juga berpotensi melanggar kode etik sebagai karyawan dari sebuah perusahaan media, seperti pernyataanya berikut ini:

"Karena itu merk sementara saya sebagai jurnalis sebagai presenter juga itu udah memegang merk media sendiri, tempat saya kerja. Jadi itu satu hal yang gak boleh saya langgar sih, jatuhnya itu sebagai kode etik karyawan juga sih." (Informan 2, Wawancara. 8 Agustus 2020)

Hal menarik lainnya yang dapat diamati dari hasil penelitian adalah meskipun telah bekerja selama lima tahun, bahkan dua belas tahun lebih sebagai jurnalis, Informan 1 dan 3 mengaku tidak pernah membaca Kode Etik Jurnalistik. Hal ini terlukis dari pernyataan Informan 1 saat ditanya mengenai kode etik jurnalistik "Waduh ya pernahlah dengar tapi jangan tanya gue poin-poinnya apa aja". Lebih lanjut Informan 1 menjelaskan bahwa dengan pekerjaanya sebagai jurnalis yang sering kali bekerja overtime dan kesibukannya mengurus keluarga, dirinya merasa tidak punya waktu untuk mempelajari Kode Etik Jurnalistik maupun mengikuti organisasi jurnalis. Keduanya hanya mengetahui kode etik jurnalistik secara umum seperti tidak diperbolehkan menerima uang atau hadiah dalam melakukan peliputan, tidak diperbolehkan melanggar privasi narasumber dan harus cover both sides dalam melakukan peliputan sebagaimana dijelaskan informan 3 "Pokoknya jurnalis tuh ga boleh menyebar hoax, terus harus menyampaikan informasi secara kredibel, objektif, lalu menggunakan bahasa yang... Apa sih istilahnya itu straight to the point dan tidak menggiring opini”.

Sementara informan 2, 4 dan 5 mengaku mengetahui dan pernah membaca kode etik jurnalistik. Bahkan juga turut menyampaikan atau menjelaskannya ketika mereka menjadi narasumber dalam sebuah seminar yang membahas mengenai dunia jurnalistik. Seperti yang disampaikan Informan 4 "Iya dong baca dong, dipresentasikan malah, ya kalau misalkan kita lagi ngisi-ngisi kelas kan kita harus memberi tahu padahal kan mah gue gak hafal sejujurnya". Meskipun penah membaca dan mengetahui kode etik jurnalistik, namun ketiganya tidak bisa menjelaskan apa saja isi kode etik jurnalistik secara detail, yang terdiri dari 11 pasal. Hal ini berbeda dengan penelitian terdahulu yang menguji pengetahuan jurnalis terkait kode etik jurnalistik. Penelitian yang dilakukan Hatta (2018) dan Purnomo (2020) menunjukkan bahwa wartawan sebenarnya sudah mengetahui dan memahami kode etik jurnalistik, namun penerapannya saja yang terkadang sulit karena juga dipengaruhi faktor ekternal. Seperti dalam membuat berita berimbang, terdapat kepentingan pemilik media yang cenderung meminta jurnalis membuat berita yang mendukung salah satu partai politik misalnya. Hasil tersebut didapatkan dari informan yang merupakan jurnalis yang tergabung dalam organisasi wartawan seperti Aliansi Jurnalis Independen (AJI).

Terkait dengan organisasi jurnalis, dapat dilihat dalam penelitian ini, pemaknaan para informan terhadap kode etik jurnalistik dipengaruhi oleh keanggotaan organisasi jurnalis. Informan 1, 3, 4 dan 5 tidak tergabung dalam organisasi wartawan baik AJI, IJTI maupun PWI. Keempatnya berasumsi bahwa kegiatan endorsement atau promosi berbayar di akun Instagram merupakan kegiatan yang sah dan wajar untuk dilakukan selama tidak membohongi publik dan tidak menerima produk yang berpotensi merusak kredibilitasnya sebagai jurnalis. Sementara Informan 2 merupakan anggota dari IJTI (Ikatan Jurnalis Televisi Indonesia) dan memiliki sertifikasi Jurnalis Utama, sertifikasi tingkat paling tinggi dalam profesi jurnalis (urutan sertifikasi dari IJTI: Jurnalis Muda, Madya dan Utama). Meskipun tidak bisa menyebutkan satu per satu pasal kode etik jurnalis, namun Informan 2 memahami bahwa kegiatan promosi berbayar walaupun dilakukan di akun media sosial pribadi, selama masih membawa profesinya sebagai jurnalis maka tidak sesuai dengan kode etik jurnalistik. Dirinya pun menambahkan bahkan kegiatan endorsement berpotensi melanggar kode etik sebagai karyawan juga, jika terhubung dengan brand besar, karena masing-masing jurnalis sudah membawa brand media 
124 | Kajian Jurnalisme

Volume 05 Nomor 02 Tahun 2022

DOI: $10.24198 / j \mathrm{kj} . v 5 \mathrm{i} 2.32822$

tempatnya bekerja.

Terkait dengan sertifikasi, Dewan Pers mengakui bahwa hingga kini masih banyak wartawan yang belum memperoleh sertifikat kompetensi, karena Dewan Pers memang tidak mewajibkan wartawan untuk mengikuti proses sertifikasi, serta tidak adanya komitmen dari perusahaan media untuk mendaftarkan wartawannya agar tersertifikasi (Indonesian Press Council, 2018; Waluyo, 2018). Untuk melaksanakan tugas di lapangan, wartawan cukup memiliki kartu pers dari perusahaan tempatnya bekerja. Namun untuk meningkatkan kualitas dan profesionalitas wartawan, terdapat program Sertifikasi Kompetensi Wartawan (SKW) hal ini tercantum dalam Peraturan Dewan Pers No. 1 tahun 2010, sebagaimana diperbarui dalam Peraturan Dewan Pers No. 4 tahun 2017 tentang Sertifikasi Kompetensi Wartawan, di mana terdapat tiga jenjang sertifikasi dimulai dari muda, madya dan utama (Indonesian Press Council, 2018). Banyak aspek yang menjadi standar kompetensi wartawan, selain skills jurnalistik yang mumpuni tentu wartawan pun harus memiliki pemahaman yang komprehensif terkait etika dan hukum terkait dengan kegiatan dan profesi wartawan (Indonesian Press Council, 2018).

Selanjutnya, Kode Etik Jurnalistik sendiri terakhir kali diperbaharui pada 14 Maret 2006. Kala itu media sosial belum ramai digunakan seperti saat ini. Sehingga dari 11 pasal yang tercantum dalam kode etik jurnalistik, belum ada pasal yang benar-benar mengatur dengan jelas tentang etika jurnalis dalam berselancar di dunia digital termasuk beraktivitas di media sosial. Untuk itu, agar tidak terjadi kesalahpahaman Dewan Pers serta organisasi terkait perlu memperbaharui kode etik jurnalistik dan menambahkan poin etika jurnalis di dunia digital. Bukan hanya pembaharuan, menurut Sulistyowati (2013) para organisasi profesi wartawan pun bertanggungjawab untuk melakukan pengawasan penerapan dan sosialisasi kode etik yang sudah ada, sehingga tidak ada kesalampahaman dalam penafsiran kode etik pada jurnalis. Dengan demikian, diharapkan jurnalis akan bekerja lebih profesional dan tidak mengikis kepercayaan publik. Karena sesuai dengan Pitakasari (2013), mencampuradukkan iklan dan kegiatan jurnalistik akan berakibat pada penurunan kepercayaan publik terhadap media atau jurnalis itu sendiri. Wacana pembaharuan kode etik jurnalistik sendiri sudah direkomendasikan sejak tahun 2012 oleh ketua Dewan Pers saat itu yakni Bagir Manan (Dem, 2012). Di tahun yang sama, Dewan Pers telah menyusun dan menandatangani Pedoman Pemberitaan Media Siber, sebagai acuan pembuatan berita digital, namun untuk kode etik sendiri belum ada penyesuaian hingga kini.

\section{Tanggapan Lingkungan Sekitar Terkait Kegiatan Endorsement}

Berdasarkan Wibawa (2012) ada beberapa aspek selain Kode Etik Jurnalistik itu sendiri, yang memengaruhi jurnalis dalam berupaya mewujudkan profesionalitas yakni kebijakan perusahaan tempatnya bekerja, perilaku rekan sejawat dan hati nuraninya sendiri. Untuk itu, penelitian ini juga menyoroti tanggapan lingkungan sekitar termasuk perusahaan media, atasan dan rekan sesama jurnalis terhadap kegiatan promosi di instragam. Hasilnya menunjukkan kurangnya kesadaran bahwa kegiatan promosi di Instagram menyalahi kode etik jurnalistik juga datang dari lingkungan sekitar para jurnalis. Kelima informan mengaku tidak pernah mendapatkan teguran dari lingkungan sekitar tentang kegiatan endorsement yang selama ini mereka lakukan. Informan mengaku berteman di Instagram dengan rekan satu pekerjaan dan juga atasannya. Atasannya tidak pernah memberikan peringatan atau melarang informan untuk melakukan endorsement, seperti yang disampaikan Informan 1 "Biasa saja sih, karena kan sesuatu yang biasa kan". Informan 1 mengungkapkan, perusahaanya tidak terlalu memantau kegiatan endorsement, namun yang pernah dilarang oleh atasannya adalah kegitan side job, ketika para presenter diundang untuk menjadi MC atau Moderator. Atasannya merasa tidak 
etis jika seorang presenter berita terlalu banyak melakukan side job apalagi jika kegiatannya diunggah di Instagram.

Selanjutnya, kembali kepada kegiatan endorsement, informan 2 juga mengungkapkan atasannya tidak mempermasalahkan, bahkan dalam beberapa kesempatan unggahan informan yang sedang merekomendasikan produk disukai atau mendapaikan 'like' dari atasannya, seperti yang disampaikan Informan 2:

"So far sih...ketika saya posting di story dia nge-view, ketika saya posting di feeds dia nge-like. It means fine yaaa. Entah itu respon atau tidak tapi itu fine. Jadi sejauh ini belum ada. Karena setahu saya, di kantor saya belum ada aturan yang secara signifikan menuliskan itu. Jadi sejauh ini sih masih...masih baik-baik aja" (Informan 2, Wawancara. 8 Agustus 2020)

Dalam keterangannya, Informan 2 pun menjelaskan bahwa kantor tempatnya bekerja belum memberikan regulasi atau peraturan bagi karyawannya terutama jurnalis yang melakukan endorsement di Instagram atau media sosial lainnya.

Sementara Informan 5 menyatakan kantornya sangat memantau kegiatan para jurnalis di media sosial, namun batasan kerasnya yang tidak boleh dilanggar adalah ketika jurnalis mengunggah koten yang menunjukkan dia tidak netral atau mendukung suatu kelompok politis tertentu. Selanjutnya terkait dengan konten promosi atau endorsement, perusahaannya atau atasannya beberapa kali memberikan arahan untuk tidak melakukan hard selling, seperti yang dikatakan Informan 5:

"Oh tahu, makannya kan itu tadi kita ga boleh hard selling karena dipantau sekali. Kalau dimarahin nggak, cuma kalau misalnya diwanti-wanti, tapi ini berlaku untuk semuanya ya. Kayak misalnya musim pilpres kemarin Aku kan sempat ada kerja sama dengan Kementerian tertentu tapi kan takutnya terafiliasi sama paslon yang mana. Nah jadi selama masa pemilihan itu ditunda dulu. Padahal kontennya tidak menyinggung soal pilpres sama sekali, tapi kan terafiliasi gitu kan. Nah jadi itu tadi ditunda, abis pilpres dilanjut lagi. Tapi kalau ditegur gak pernah.” (Informan 5, Wawancara. 9 Agustus 2020)

Dalam penjelasanya, Informan 5 menyatakan sejauh ini ia belum pernah mendapat teguran karena dirinya membuat konten yang sesuai dengan kesehariannya saja dan menolak permintaan untuk hard selling. Dirinya menambahkan, terkadang ada saja klien yang meminta untuk membuat konten hard selling, namun ia sering menolak meskipun ditawarkan bayaran yang tinggi.

Selanjutnya, Informan 4 justru pernah memberikan teguran pada rekan sesama jurnalisnya, karena pernah melihat rekannya merekomendasikan produk yang berpotensi merusak kredibilitasnya, seperti yang dijelaskan berikut ini:

"Pokoknya kalo produk-produknya kayaknya tuh gak cocoklah dengan profesi lu gitu ya yang lu tuh gak background check dulu gitu misalkan produknya apa gitu. Ya misalkan kaya gitu deh program-program buat mukalah katakan lu paham gak misalkan itu isinya ada merkurinya atau engga, kandungan-kandungan kimia yang kaya gitu-gitu kan kita harus lebih teliti jangan sampe justru menyesatkan masyarakat gitu kan kita tanggung jawab sosialnya lebih besar dairpada selebgram lainnya, gitu." (Informan 4, Wawancara. 8 Agustus 2020)

Dalam keterangannya, Informan 4 menyatakan tanggung jawab jurnalis televisi lebih besar dari pada selebgram lainnya. Lebih lanjut dia menjelaskan, tanggung jawab yang dimaksud adalah jurnalis membawa nama media dan berperan penting dalam menyampaikan informasi bagi masyarakat luas, maka jurnalis perlu untuk menjaga citranya, untuk tetap terlihat pintar, berwibawa dan dapat dipercaya. Ketika jurnalis turut mempromosikan produk yang tidak masuk akal, maka tentu akan menciderai citranya dan berpotensi mengurangi kepercayaan publik baik pada jurnalis itu sendiri maupun perusahaan media tempatnya berkerja.

Dengan segala pertimbangan yang telah dijelaskan di atas, informan 1, 3, 4 dan 5 
menyatakan untuk kedepannya masih berniat melanjutkan kegiatan endorsement karena merasa hal tersebut tidak melanggar kode etik jurnalistik, dengan tujuan utama untuk membantu rekanrekan pengusaha UMKM. Namun tentu dengan syarat dan ketentuan yang berlaku, seperti memilih produk yang sesuai, yang tidak merusak kredibilitasnya sebagai jurnalis dan tetap membuat pesannya dalam bentuk promosi tidak langsung (soft-selling). Sementara Informan 2 menyatakan akan lebih berhati-hati, bahkan menolak untuk melakukan kegiatan endorsement yang berafiliasi dengan brand besar, karena menyadari hal tersebut tidak sesuai dengan kode etik jurnalis. Adapun selama ini kegiatan endorsement yang ia lakukan lebih kepada membantu teman di sekitarnya yang sedang membangun usaha.

\section{SIMPULAN}

Sosial media Instagram digunakan para jurnalis televisi untuk beberapa alasan seperti membentuk citra pribadi (personal branding), membangun jejaring sosial (social networking), serta sarana untuk mencari infomasi dan hiburan. Para jurnalis biasanya mengunggah konten berupa aktivitas sehari-hari termasuk kegiatannya sebagai jurnalis seperti ketika sedang siaran atau melakukan liputan langsung di lapangan. Karena jumlah followers atau pengikutnya yang banyak yakni melebihi dua puluh ribu akun, maka para jurnalis kerap kali mendapatkan tawaran endorsement atau promosi produk dari teman dekat yang memiliki usaha ataupun dari brand besar. Informan 1, 2 dan 4 tidak memberikan harga khusus untuk jasa endorsement, sementara Informan 3 dan 5 memiliki rate card khusus dengan tarif 2-3 juta rupiah per unggahan dapat berupa foto atau video. Motivasi utama para informan untuk menerima permintaan endorsement adalah untuk membantu usaha mikro, kecil dan menengah dalam mempromosikan produknya. Namun karena proses produksi konten memerlukan upaya dan tenaga, maka mereka menerapkan tarif khusus. Untuk brand besar mereka menerapkan tarif yang lebih besar karena perusahaanya sudah jauh lebih stabil secara keuangan dibadingkan UMKM.

Bagi informan 1, 3, 4 dan 5, yang tidak tergabung dengan organisasi jurnalis dan tidak memiliki sertifikasi jurnalis, kegiatan endorsement di Instagram sekalipun melibatkan brand besar, tidak melanggar kode etik jurnalistik, asalkan dilakukan dengan cara yang baik yakni mengulas berdasarkan fakta dan jujur, tidak menyebarkan kebohongan, serta tidak mempromosikan produk yang berpotensi menghancurkan kredibilitas jurnalis seperti pemutih kulit, pelangsing atau pembesar payudara instan yang tidak masuk akal. Sementara, bagi Informan 2, yang tergabung dalam IJTI dan memiliki sertifikasi jurnalis utama, kegiatan endorsement memang seharusnya tidak dilakukan karena melanggar kode etik jurnalistik serta berpotensi juga menyalahi kode etik sebagai karyawan, karena dirinya sudah merepresentasikan brand media tempatnya bekerja. Dari hasil temuan tersebut, terlihat adanya pergeseran nilai kode etik jurnalistik pada jurnalis televisi yang melakukan kegiatan endorsement di Instagram. Berdasakan kode etik jurnalistik dalam pasal 1 dan 6 , jurnalis haruslah independen dan tidak menyalahgunakan profesinya untuk kepentingan suatu pihak tertentu. Kegiatan promosi biasanya merupakan ranah pekerja hiburan seperti bintang iklan dan film. Hal ini menunjukkan bahwa keanggotaan organisasi wartawan dan kepemilikan sertifikasi wartawan memengaruhi pemahaman jurnalis terhadap kode etik jurnalistik. Jurnalis yang bergabung dengan organisasi dan memiliki sertifikasi lebih memahami kode etik jurnalis dibandingkan yang tidak. Kode etik jurnalistik sendiri terakhir kali diperbaharui pada 14 Maret 2006, saat itu sosial media belum berkembang seperti masa kini. Jadi belum ada pasal khusus yang membahas mengenai kegiatan promosi di media sosial untuk jurnalis. Untuk itu, Dewan Pers serta sejumlah pihak terkait harus segera memperbaharui kode etik yang ada, agar tidak terjadi pergeseran makna dari etika yang sebenarnya, agar jurnalis bisa lebih profesional dalam menjalani tugasnya sehingga tidak 
Volume 05 Nomor 02 Tahun 2022

DOI: $10.24198 / j \mathrm{kj} . \mathrm{v} 5 \mathrm{i} 2.32822$

mengikis kepercayaan publik.

\section{DAFTAR PUSTAKA}

Alfindra, M. F., \& Yahya, M. (2017). Motivasi mahasiswa bergabung dalam media sosial Instagram. Jurnal Ilmiah Mahasiswa FISIP Unsyiah, 2(3). Diakses dari http://www.jim. unsyiah.ac.id/FISIP/article/view/3659

Andriawan, I. (2016). Fenomena Instagram sebagai media pemasaran (Universitas Islam Bandung). Universitas Islam Bandung. Diakses dari http://repository.unisba.ac.id/ handle $/ 123456789 / 3076$ ?show $=$ full

Breves, P. L., Liebers, N., Abt, M., \& Kunze, A. (2019). The perceived fit between instagram influencers and the endorsed brand: How influencer-brand fit affects source credibility and persuasive effectiveness. Journal of Advertising Research, 59(4), 440-454. https:// doi.org/10.2501/JAR-2019-030

Bungin, M. B. (2011). Pelitian kualitatif; komunikasi, ekonomi, kebijakan publik, dan ilmu sosial lainnya. Jakarta: Kencana.

De Veirman, M., Cauberghe, V., \& Hudders, L. (2017). Marketing through Instagram influencers: the impact of number of followers and product divergence on brand attitude. International Journal of Advertising, 36(5), 798-828. https://doi.org/10.1080/02650487 .2017 .1348035

Dem. (2012). Kode etik jurnalistik perlu diperbaharui. Diakses dari Rmol.id website: https:// politik.rmol.id/read/2012/12/27/91781/Kode-Etik-Jurnalistik-Perlu-Diperbaharui-

Dewan Pers Republik Indonesia. (2006). Indonesian journalist code of ethics.

Elliot, D., \& Spence, E. H. (2017). Ethics for a digital era. Oxford: Wiley.

Febriana, M. (2017). Hiperrealitas "endorse" dalam Instagram studi fenomenologi tentang dampak media Sosial di kalangan mahasiswa Universitas Sebelas Maret. Jurnal Analisa Sosiologi, 6(2), 18-29. https://doi.org/10.20961/jas.v6i2.18098

Hatta, H. (2018). Tingkat pengetahuan dan pemahaman wartawan terhadap kode etik jurnalistk (Wartawan kota Makassar). Jurnal Jurnalisa, 4(2), 241-255. https://doi.org/10.24252/ jurnalisa.v4i2.6897

Herdiansyah, H. (2010). Metode penelitian kualitatif untuk ilmu-ilmu sosial. Jakarta: Salemba Humanika.

Indonesian Press Council. (2018). Pentingnya sertifikasi kompetensi wartawan. Diakses dari Dewan Pers website: https://dewanpers.or.id/publikasi/opini_detail/149/Pentingnya_ Sertifikasi_Kompetensi_Wartawan

Kothari, C. R. (2004). Research methodology: Methods and techniques (2nd ed.). New Delhi: New Age International Publishers.

Mego, K. A. A., Budiartha, I. N. P., \& Ujianti, N. M. P. (2021). Tinjauan yuridis terhadap selebgram yang melakukan endorse/promosi barang ilegal pada produk obat-kosmetik. Jurnal Konstruksi Hukum, 2(2), 271-276. https://doi.org/10.22225/jkh.2.2.3219.271-276

Mubarikah, N. A. (2021). Kewajiban endorser atas penganjuran suatu produk pada media sosial menurut peraturan perundang-undangan di Indonesia dalam perbandingan dengan Amerika Serikat, Inggris dan India. Dharmasisya, 1(1), 402-415. Diakses dari https:// scholarhub.ui.ac.id/dharmasisya/vol1/iss1/13/

Muela-Molina, C., Martin-Santana, J., \& Reinaress-Lara, E. (2020). Journalists as radio advertising endorsers in news or talk radio stations. Journalism, 21(12), 1913-1931. https://doi.org/10.1177/1464884917753785

Patimah, S., \& Gorda, A. A. N. O. S. (2017). Strategi social media marketing: Model 
128 | Kajian Jurnalisme

Volume 05 Nomor 02 Tahun 2022

DOI: $10.24198 /$ jkj.v5i2.32822

endorsement selebgram. Jurnal Manajemen Bisnis, 14(2), 151-174. Diakses dari https:// journal.undiknas.ac.id/index.php/magister-manajemen/article/view/345

Pitakasari, A. R. (2013). "Pisahkan wartwan dengan pencari iklan." Diakses dari republika. co.id website: https://www.republika.co.id/berita/nasional/umum/13/05/16/mmwfjypisahkan-wartawan-dengan-pencari-iklan

Pramesti, O. L. (2014). Penerapan kode etik di kalangan jurnalis. Jurnal ILMU KOMUNIKASI, 11(1), 81-92. https://doi.org/10.24002/jik.v11i1.386

Purnomo, E. (2020). Studi kode etik jurnalistik oleh wartawan pada pasal 6 (Institut Agama Islam Negeri Metro). Institut Agama Islam Negeri Metro. Diakses dari https://repository. metrouniv.ac.id/id/eprint/3867/

Sulistyowati, F. (2013). Organisasi profesi jurnalis dan kode etik jurnalistik. Jurnal ILMU KOMUNIKASI, 3(2), 119-129. https://doi.org/10.24002/jik.v3i2.234

Syahreza, M. F., \& Tanjung, I. S. (2018). Motif dan pola penggunaan media sosial Instagram di kalangan mahasiswa Program Studi Pendidikan Ekonomi UNIMED. Jurnal Interaksi, 2(1), 61-84. Diakses dari http://jurnal.umsu.ac.id/index.php/interaksi/article/view/1788

Waluyo, D. (2018). Tinjauan standar kompetensi wartawan untuk meningkatkan kapasitas media dan profesionalisme. Jurnal Studi Komunikasi Dan Media, 22(2), 167-184. https:// doi.org/10.31445/jskm.2018.220206

Wati, H. (2019). Pengaruh selebgram sebagai celebrity endorsement terhadap perilaku konsumtif mahasiwi. Sosietas Jurnal Pendidikan Sosiologi, 9(2), 722-727. https://doi. org/10.17509/sosietas.v9i2.22822

Wibawa, D. (2012). Meraih profesionalisme wartawan. MIMBAR, Jurnal Sosial Dan Pembangunan, 28(1), 113-122. https://doi.org/10.29313/mimbar.v28i1.345 